\title{
The Efficiency of Red Chili Farming In Merapi Eruption Area, Yogyakarta, Indonesia
}

\author{
Lestari Rahayu ${ }^{1, *}$ and Dwi Febriani ${ }^{1}$ \\ ${ }^{1}$ Department of Agribusiness, Universitas Muhammadiyah Yogyakarta, Jl. Brawijaya, Geblagan, \\ Tamantirto, Kasihan, Bantul, Daerah Istimewa Yogyakarta 55183, Indonesia
}

\begin{abstract}
Changes in soil texture after the Merapi eruption in 2010 does not affect farmers in using the production factors, resulting in non-optimal production. This study aims to analyze the factors affecting red chili production and the level of technical, allocative, and economic efficiency of red chili farming in the Merapi eruption area, Sleman Regency Yogyakarta. This study utilized a quantitative method. A total of 80 farmers was selected as samples by using a simple random sampling method. Data were analysed using the Cobb-Douglas Stochastic Frontier production model. The input side approach analysed the allocative and economic efficiency. The results showed that only land area and manure factors that significantly affected the production of red chili. The average of farmers had reached technical efficiency level with an index of 0.826 and allocative efficiency level with an index of 0.804 . However, they had not achieved economic efficiency because the efficiency level merely reached the 0.665 indexes. Meanwhile, four internal factors of farmers, namely age, education level, farming experience, and land ownership status, had an insignificant influence on technical inefficiencies.
\end{abstract}

\section{Introduction}

Chili is one of the horticulture plants that have been chosen to be cultivated because it has a high selling value. However, the increase in chili production in Indonesia cannot meet the increasing community needs, causing chili to influence the inflation rate almost every year. This statement is reflected in the increase in chili production in 2013, which continued to produce a deficit of up to 0.2 million tons (Ministry of Agriculture's Renstra, 2015) due to crop failure caused by the lack of water [1].

Land in the Merapi eruption area has wet properties that are suitable for planting red chili. The eruption of Mount Merapi in 2010 resulted in the death of all agriculture in the Yogyakarta Special Region. According to [2], in general, the material spewed out of Mount Merapi, namely volcanic ash, hot lava, and cold lava, can cause damage to land and water resources, including agricultural infrastructure. The volcanic sand and ash are deposited on the farm, causing the plants covered with volcanic ash. Moreover, cold and hot lava can directly damage the agricultural land in the Merapi Eruption area as they pass through.

\footnotetext{
* Corresponding author: lestari@umy.ac.id
} 




Fig. 1. Chili Productivity (ton/ha) in Merapi Eruption Area Cangkringan Sleman District [3]

After the eruption of Merapi, red chili farming activities had been halted for some time due to farmers' limited capital and a long time land recovery. These issues affected red chili production in Wukirsari Village, in which the productivity in 2011 was very low, reaching merely 3.44 tons per hectare. Although the productivity of red chili from 2012 to 2014 showed an upward trend, however, but after 2014 it had decreased (Figure 1).

The change in soil texture after the eruption of Merapi does not affect farmers in utilizing the production factors, meaning that farmers tend to add or reduce them based on customs. It can lead to inefficiencies in the use of production factors. Such a situation is the same as the study of [4] in Ghana's poor soil quality, where the slope of the land reduced the efficiency of chili farming techniques. Furthermore, there are internal factors from farmers, such as education level, farmers' age, experience, and land ownership status that can affect the emergence of farmers' technical inefficiencies. It is consistent with the statement of Bokhuseva \& Hokmann (2004) in [5], stating that farming efficiency and technological innovation can affect productivity. Farmers' efforts to improve technology are generally faced with the problem of limited capital, causing the procurement of technology becomes relatively slow and even stagnant in the short term. In a fixed technological condition, farm efficiency greatly influences productivity.

There have been several studies examining the efficiency of red chili farming such as [6], [5], and [7] in sandy areas that technically were not yet efficient and allocative. In large red chili cultivation, there were indications of excessive use of $\mathrm{N}, \mathrm{P}_{2} \mathrm{O}_{5}$, and PPC fertilizers, and lack of use of K2O5 fertilizer, growth regulator (ZPT), organic fertilizer, lime, and pesticides. In contrast to the results of research by [8] concerning the efficiency of red chili production in Central Java Province that showed that the level of achieving technical efficiency is classified as large red chili and curly red chili. It indicates that the mastery and application of farmer technology and management capabilities had been good. In accordance with the research results conducted by [4] in Ghana's education, extension visits, closeness to markets, and access to credit tended to increase the technical efficiency of farmers.

To optimize the production of red chili in the Merapi eruption area, it is necessary to conduct a study on the efficiency of red chili farming, which includes its technical, allocative, and economic efficiency. 


\section{Research Method}

The study was conducted in Wukirsari Village, Cangkringan District, Sleman Regency because it is located on the slope of Mount Merapi, of which the land is suitable for food and horticultural crops such as red chili. The sample consisted of 80 respondents determined by simple random sampling.

The data collected were analyzed using the Cobb-Douglas Frontier production function, which was transformed into a linear natural logarithmic form [9]. This analysis explained the effect of the use of production factors (Xi) on the amount of red chili production (Y) in one planting season in 2017, with the following equation model:

$$
\begin{aligned}
\ln Y= & \ln \beta 0+\beta 1 \ln X 1+\beta 2 \ln X 2+\beta 3 \ln X_{3}+\beta 4 \ln X_{4}+\beta 5 \ln X_{5}+\beta 6 \ln X_{6}+\beta 7 \ln X_{7}+ \\
& \beta 8 \ln X_{8}+\beta 9 \ln X_{9}+v_{i}-u_{i}
\end{aligned}
$$

Factors presumed affecting the red chili farming examined in this study included land area $\left(\mathrm{X}_{1}\right)$, red chili seedlings $\left(\mathrm{X}_{2}\right)$, manure $\left(\mathrm{X}_{3}\right)$, NPK Mutiara fertilizer $\left(\mathrm{X}_{4}\right)$, Phonska fertilizer $\left(\mathrm{X}_{5}\right)$, insecticide $\left(\mathrm{X}_{6}\right)$, fungicide $\left(\mathrm{X}_{7}\right)$, family labor/TKDK $\left(\mathrm{X}_{8}\right)$, and non-family labor/TKLK (X9). Factor vi explained the disturbance terms which were useful for calculating the size of the error made due to random taking. The ui factor indicated that an internal farmer could influence the inefficiency determined through the following equation:

$$
u_{i}=\delta_{0}+\delta_{1} Z_{1}+\delta_{2} Z_{2}+\delta_{3} Z_{3}+\delta_{4} Z_{4}
$$

The internal factors of farmers included age $\left(Z_{1}\right)$, education level $\left(Z_{2}\right)$, farming experience $\left(Z_{3}\right)$, and dummy land tenure $\left(Z_{4}\right)$. Equations (1) and (2) were then analyzed simultaneously using the Maximum Likelihood Estimation (MLE) method utilizing Frontier 4.1 software. The results of this analysis also jointly produced the value of the technical efficiency of the red chili farming as measured by the following equation:

$$
T E_{i}=\frac{Y_{i}}{Y_{i}^{*} *}=\frac{E\left(Y \mid u_{i}, X_{i}\right)}{E\left(Y \mid u_{i}=0, X_{i}\right)}=E\left[\exp \left(-u_{i}\right) / \varepsilon_{i}\right]
$$

Notes:

$\mathrm{TE}_{\mathrm{i}}=$ Technical efficiency of farmers to the $\mathrm{i}$ with values ranging between 0 and 1

$\mathrm{Y}_{\mathrm{i}}=$ Output produced by farmers to the $\mathrm{i}$

$\mathrm{Y}_{\mathrm{i}}^{*}=$ Potential output (obtained from the stochastic frontier production function)

If the technical efficiency value is closer to 1 (one), then the red chili farming can be said to be more technically efficient. According to [10], in addition to technical efficiency, the concept of efficiency can also be described through price or allocative efficiency and economic efficiency. [5] describes price or allocative efficiency as the ability of farmers to produce several outputs on the condition of minimizing the input cost ratio. As for economic efficiency, according to [11], refers to a combination of technical and price efficiency.

Furthermore, to measure economic efficiency, it is necessary to reduce the dual cost function from the homogeneous Cobb-Douglas production function [12]. According to [13] , the calculation of economic efficiency is obtained through the relationship between the total minimum production costs written with $\left(\mathrm{C}^{*}\right)$ and the total actual production costs $(\mathrm{C})$, which are mathematically written as follows:

Notes:

$$
E E=\frac{C^{*}}{C}
$$

$\mathrm{EE}=$ Economic efficiency

$\mathrm{C}^{*} \quad=$ Minimum total costs observed

$\mathrm{C} \quad=$ Total actual production costs

EE values range between 0 and 1 . 
However, in Frontier 4.1 software calculations, the value obtained is in the form of cost efficiency (CE), which can be written in the following equation:

$$
\begin{aligned}
\ln C= & \beta 0+\beta 1 \ln Y+\beta 2 \ln P 2+\beta 3 \ln P_{3}+\beta 4 \ln P_{4}+\beta 5 \ln P_{5}+\beta 6 \ln P_{6}+\beta 7 \ln P_{7}+\beta 8 \\
& \ln P_{8}+\beta 9 \ln P_{9}+\mathrm{v}_{\mathrm{i}}-\mathrm{u}_{\mathrm{i}}
\end{aligned}
$$

The cost efficiency factors included in the equation consisted of red chili production (Y), seedlings price $\left(\mathrm{X}_{2}\right)$, manure price $\left(\mathrm{X}_{3}\right)$, NPK Mutiara fertilizer price $\left(\mathrm{X}_{4}\right)$, Phonska fertilizer price $\left(\mathrm{X}_{5}\right)$, insecticide value $\left(\mathrm{X}_{6}\right)$, fungicide price $\left(\mathrm{X}_{7},\right)$, TKDK price $\left(\mathrm{X}_{8}\right)$ and TKLK price $\left(\mathrm{X}_{9}\right)$. Then, the value of cost efficiency, according to Ogundari \& Ojo (2007) referring to Coelli et al. (1998), explained that the cost efficiency estimation results are calculated based on the inverse of equation (4). Thus, economic efficiency is obtained through the following equation:

$$
E E=\frac{1}{\text { Cost Effeciency }(C E)}
$$

After obtaining the economic efficiency value, then the price or allocative efficiency value can be calculated from the following equation:

Notes:

$$
A E=\frac{E E}{T E}
$$

$\mathrm{AE}=$ Allocative efficiency

$\mathrm{EE}=$ Economy efficiency

$\mathrm{TE}=$ Technical efficiency

$\mathrm{AE}$ values range between $1>\mathrm{AE}>1$.

$\mathrm{AE}=1$, resource is efficiently utilized

$\mathrm{AE}>1$, indicates under-utilization of resources

$\mathrm{AE}<1$, indicates over-utilization of resources [14]

\section{Results and Discussion}

\subsection{The Use of Red Chili Production Factors}

The use of production factors, both quantity and type, greatly influence production yields, known to be related to efficiency levels. Determination of the number of production factors tends to be influenced by the area of land owned by farmers, while the selection of species is influenced by the availability of funds and farmers' needs in production activities.

The seedling used by farmers was TM99 variety. This variety was deemed to produce high-quality products and more resistant to diseases, such as streak and fungal diseases, especially during the rainy season. For farmers, the use of manure was a necessity. Farmers' habit in using manure has been done for a long time. They believed the use of manure as basic fertilizer would provide more nutrients and make the growth of chili plants better. They frequently used cow manure as fertilizer as most of them raised cows.

However, chemical fertilizer was also needed as it had a rapid influence on the growth of red chili plants. Chemical fertilizer used by farmers included ZA, NPK Mutiara, Phonska, and Urea. Nevertheless, there were only several farmers using ZA and Urea. Most of them tended to combine chemical and organic fertilizers as the basic fertilizer. Meanwhile, NPK Mutiara and Phonska were used as supplementary fertilizer.

Pesticides used by farmers included insecticides and fungicides. Pesticides are used to maintain production potential. Fungicides were used to control diseases caused by fungi that were susceptible after chili plants fruiting, such as anthracnose. In general, the use of pesticides was influenced by the needs to prevent or control the disease. On average, farmers sprayed 8 to 16 times of pesticides for one planting period. 
Table 1. Average Use of Production Factors in Red Chili Farming in Wukirsari Village

\begin{tabular}{|l|r|r|}
\hline \multicolumn{1}{|c|}{ Production Factors } & Per Farming (0.1018 Ha) & Per Hectare \\
\hline Seedlings (tree) & $\mathbf{2 . 0 9 4}$ & $\mathbf{2 0 . 1 7 4}$ \\
\hline Organic Fertilizer (kg) & $\mathbf{3 5 0 . 0 0}$ & $\mathbf{3 , 3 6 1 . 3 2}$ \\
\hline Chemical Fertilizer & & \\
\hline 1. ZA Fertilizer(kg) & 2.09 & 27.89 \\
\hline 2. NPK Mutiara Fertilizer (kg) & 9.64 & 107.16 \\
\hline 3. Phonska Fertilizer (kg) & 13.47 & 174.83 \\
\hline 4. Urea Fertilizer (kg) & 3.81 & 62.26 \\
\hline Insecticide & & \\
\hline 1. Bamex (ml) & 64.89 & 733.81 \\
\hline 2. Buldok (ml) & 59.70 & 861.20 \\
\hline Fungicide & & \\
\hline 1. Bion-M (kg) & 0.03 & 0.37 \\
\hline 2. Antracol (kg) & 0.23 & 2.34 \\
\hline Labor & & \\
\hline 1. Family (HKO) & 18.26 & 212.91 \\
\hline 2. Non-family (HKO) & 5.98 & 46.07 \\
\hline Production (kg) & $\mathbf{5 9 5 . 5 0}$ & $\mathbf{5 , 8 8 8 . 7 5}$ \\
\hline
\end{tabular}

Workers in red chili farming activities consisted of two types, family labor (TKDK) and non-family labor (TKLK). The activities of the red chili production comprised land processing, planting, fertilizing (casting), weeding, replanting, spraying, harvesting, postharvesting, and transportation. The overall production activities were mostly carried out by men, while women were more involved in weeding, harvesting, and post-harvesting activities. Based on calculations, it was known that land management and harvesting were activities requiring the most labor. Therefore, farmers usually involved workers outside the family (TKLK).

\subsection{Analysis of Frontier Production Function}

The results in Table 2 show that the log-likehood value of MLE (-22.51) is greater than the log-likehood value of OLS (-25.16). Hence, the production function could describe the conditions in the field. The sigma-squared estimation results show a value of less than one $(<1)$, which is equal to 0.844 . Thus, it can be concluded that the error term of inefficiency in red chili farming is normally distributed. Moreover, the gamma value indicates 0.922 , which can be interpreted that $92.2 \%$ of the variation of red chili production in Wukirsari Village was caused by differences in technical efficiency and the remaining $7.8 \%$ was caused by other external factors (noise), such as pests disease and climate.

Estimation results show that only the variable of land area and manure in red chili production are significant at a 99\% confidence level. The area of land provides the greatest value, causing the variable of land most responsive to increase red chili production. This result is in line with the research of [15] and [16] concerning chili efficiency, which revealed that land provided a positive value and had a significant effect on chili production.

The addition of manure also significantly increased the production of red chili. This finding is consistent with the research of [17] and [8]revealing that manure gave a positive and significant value at a $99 \%$ confidence level.

Seedlings coefficient, NPK Mutiara fertilizer, and fungicide show positive but insignificant parameters, indicating a tendency that the addition of each of seedling production factors, NPK mutiara, and fungicides could increase red chili production in Wukirsari Village, Cangkringan District. 
Table 2. Estimation Results of the Cobb-Douglas Production Function using the Frontier Approach

\begin{tabular}{|l|l|r|r|r|}
\hline No. & \multicolumn{1}{|c|}{ Variable } & Coefficient & \multicolumn{1}{c|}{ Standard-error } & \multicolumn{1}{c|}{ t count } \\
\hline 1. & Constant & 0.298 & 0.919 & -1.315 \\
\hline $\mathbf{2 .}$ & Land Area $\left(\mathbf{X}_{1}\right)$ & $\mathbf{0 . 8 6 5}^{* * * *}$ & $\mathbf{0 . 2 9 0}$ & $\mathbf{2 . 9 7 9}$ \\
\hline 3. & Seedlings $\left(\mathrm{X}_{2}\right)$ & 0.049 & 0.167 & 0.296 \\
\hline $\mathbf{4 .}$ & Organic Fertilizer $\left(\mathbf{X}_{3}\right)$ & $\mathbf{0 . 2 7 7}^{* * * *}$ & $\mathbf{0 . 1 0 0}$ & $\mathbf{2 . 7 6 7}$ \\
\hline 5. & NPK Mutiara Fertilizer $\left(\mathrm{X}_{4}\right)$ & 0.033 & 0.036 & 0.919 \\
\hline 6. & Phonska Fertilizer $\left(\mathrm{X}_{5}\right)$ & -0.014 & 0.029 & -0.473 \\
\hline 7. & Insecticide $\left(\mathrm{X}_{6}\right)$ & -0.122 & 0.061 & -0.199 \\
\hline 8. & Fungicide $\left(\mathrm{X}_{7}\right)$ & 0.0008 & 0.017 & 0.050 \\
\hline 9. & TKDK $\left(\mathrm{X}_{8}\right)$ & -0.085 & 0.292 & -0.291 \\
\hline 10. & TKLK $\left(\mathrm{X}_{9}\right)$ & -0.020 & 0.033 & -0.594 \\
\hline Sigma-squared & 0.844 & & \\
\hline Gamma & 0.922 & & \\
\hline Log-likehood OLS & -25.16 & & \\
\hline \multicolumn{2}{|l|}{ Log-likehood MLE } & -22.51 & & \\
\hline
\end{tabular}

Other variables, such as Phonska fertilizer, insecticide, fungicide, TKDK, and TKLK show negative and insignificant parameters. Therefore, it can be interpreted that the addition of each of those variables could reduce the production of red chili in Wukirsari Village.

\subsection{Technical Efficiency}

Red chili farming in Wukirsari can be stated efficient if it can produce maximum output using several certain production factors. The distribution results and the level of technical efficiency of red chili farmers were obtained from the Frontier 4.1 program using the Stochastic Frontier Analysis (SFA) parametric approach as shown in Table 3.

Table 3. Distribution and Technical Efficiency Level of Respondents from Red Chili Farmers in Wukirsari Village

\begin{tabular}{|l|r|r|}
\hline \multicolumn{1}{|c|}{$\begin{array}{c}\text { Distribution of Technical } \\
\text { Efficiency Index }\end{array}$} & Number of Farmers & \multicolumn{2}{|c|}{ Percentage (\%) } \\
\hline$\leq 0.500$ & 2 & 2.50 \\
\hline $0.501-0.600$ & 3 & 3.75 \\
\hline $0.601-0.700$ & 4 & 5.00 \\
\hline $0.701-0.800$ & 12 & 15.00 \\
\hline $0.801-0.900$ & 44 & 55.00 \\
\hline $0.901-1.000$ & 15 & 18.75 \\
\hline Total & 80 & 100.00 \\
\hline Maximum & 0.940 & \\
\hline Minimum & 0.344 & \\
\hline Mean efficiency & 0.826 & \\
\hline
\end{tabular}

Table 3 presents that the average technical efficiency achieved by farmers in the study area is 0.826 , with the lowest distribution of efficiency values is 0.344 and the largest is 0.940 . According to [18], technical efficiency is stated to be efficient if the index is greater than $0.7(>0.700)$. It means that the average value of the technical efficiency of red chili farming in Wukirsari Village had been technically efficient. The technical efficiency of farmers in producing red chili still had a $17.4 \%$ chance that could be achieved by improving farm management, such as adding production factors significantly affected the production number. 
There were $71(88.75 \%)$ out of 80 farmers who had reached an efficiency level above $0.700(>0.700)$. It indicates that 9 farmers or the rest were technically inefficient. The existence of differences in the level of individual efficiency cannot be separated from various factors, namely external factors that are not examined and internal factors of farmers.

Achieving different levels of technical efficiency can be caused by the mastery level of the application of technology used by farmers that are closely related to the attributes inherent in farmers, such as age, education, and farming experience [19].

The factors presumed to influence the technical inefficiency of the red chili farming in Wukirsari Village were age, education level, farming experience, and dummy land tenure status.

Table 4. Estimation of Technical Inefficiency Effects of Red Chili Farmer Respondents in Wukirsari Village

\begin{tabular}{|c|l|r|r|}
\hline Parameters & \multicolumn{1}{|c|}{ Variable } & \multicolumn{1}{c|}{ Coefficient } & \multicolumn{1}{c|}{ t-count } \\
\hline$\delta_{0}$ & Constant & -2.885 & -0.189 \\
\hline$\delta_{1}$ & Age $\left(\mathrm{Z}_{1}\right)$ & 0.061 & $0.244^{\mathrm{ns}}$ \\
\hline$\delta_{2}$ & Education level $\left(\mathrm{Z}_{2}\right)$ & -0.161 & $-0.195^{\mathrm{ns}}$ \\
\hline$\delta_{3}$ & Farming experience $\left(\mathrm{Z}_{3}\right)$ & -0.003 & $-0.041^{\mathrm{ns}}$ \\
\hline$\delta_{4}$ & Land tenure status $\left(\mathrm{Z}_{4}\right)$ & -2.387 & $-0.239^{\mathrm{ns}}$ \\
\hline
\end{tabular}

Notes: Ns: not significant

Based on the estimation results in Table 4, there are no significant internal factors of farmers. However, the value obtained is as presumed, namely, the age factor showing a positive value, meaning that the older the farmers, the higher the level of inefficiency that will be encouraged. This result is as presumed because chili farming required a large amount of energy for intensive care requiring productive energy. It is in agreement with the studies of [8] and [20] revealing that the inefficiency of old age factors could be caused by the inability of farmers to adopt better technology, thus impacting technical inefficiencies.

Furthermore, education level, farming experience, and dummy land tenure status, show negative values, meaning that the higher the education level and the longer the experience of the farmers, the lower the inefficiency level. Higher education will increase the ability of farmers to adopt new technologies because they are driven by farmers' knowledge, skills, and curiosity about new things. It also applies to the research of [19] providing the results of the allegation that education level affected the technical inefficiency of shallot farming in Bantul Regency by showing negative parameters.

In terms of experience, the average of farmers in Wukirsari Village belonged to the category of experienced farmers, resulting in them becoming more selective in choosing technology applications for their farming activities. The same result applies to the research of [8] showing the coefficient of experience of family heads (KK) that had negative and unreal parameters. It could be caused by the more advanced ability of farmers to innovate and adapt. Moreover, the long experience will expand networking and make managerial capabilities better.

Meanwhile, the dummy land tenure status indicates that it would increase inefficiency. It was presumably because most farmers who had their own land status were likely to make the red chili farming as their primary livelihood. Therefore, farmers would utilize their land by optimizing available inputs, resulting in more efficient farming. This study is in line with research by [21] discovering that the variable of dummy land status had a negative coefficient and insignificantly affected the technical inefficiency of lowland rice farming in Bali Province. It was presumed as such because both owner and non-owner farmers had an interest in obtaining maximum results. 


\subsection{Cost Efficiency}

Cost efficiency is the ability to produce specific outputs with minimal costs, given the price of the input. It requires to be obtained considering that the Frontier 4.1 program could only analyze technical efficiency (TE) and cost efficiency (CE). Through this cost efficiency results, the value of economic efficiency (EE) would be obtained. The concept of cost efficiency is almost the same as technical efficiency, in which only the value analyzed in the cost efficiency is obtained from the input unit price used by farmers. The analysis results of the cost efficiency of red chili farmers in Wukirsari Village are presented in the following table.

Table 5. Estimated Results of the Cobb-Douglas Cost Function Using the Stochastic Frontier Analysis Approach

\begin{tabular}{|l|l|r|r|r|}
\hline No. & \multicolumn{1}{|c|}{ Variable } & Coefficient & $\begin{array}{c}\text { Standard- } \\
\text { error }\end{array}$ & t-count \\
\hline 1. & Constant & $0.177^{* * *}$ & 2.337 & -0.740 \\
\hline 2. & Red Chili Production & $\mathbf{- 0 . 3 1 8}$ & $\mathbf{0 . 1 2 6}$ & $\mathbf{- 2 . 5 3 3}$ \\
\hline 3. & Seedlings $\left(\mathbf{X}_{2}\right)$ & $\mathbf{0 . 4 9 9})^{* *}$ & $\mathbf{0 . 2 6 4}$ & $\mathbf{1 . 8 8 5}$ \\
\hline 4. & Organic Fertilizer $\left(\mathrm{X}_{3}\right)$ & -0.003 & 0.005 & -0.655 \\
\hline 5. & NPK Mutiara Fertilizer $\left(\mathrm{X}_{4}\right)$ & $-0.011^{* * *}$ & 0.006 & -1.621 \\
\hline 6. & Phonska Fertilizer $\left(\mathbf{X}_{5}\right)$ & $\mathbf{0 . 1 1 9}$ & $\mathbf{0 . 0 4 3}$ & $\mathbf{2 . 7 5 6}$ \\
\hline 7. & Insecticide $\left(\mathrm{X}_{6}\right)$ & $0.006^{* *}$ & 0.004 & 1.363 \\
\hline 8. & Fungicide $\left(\mathbf{X}_{7}\right)$ & $\mathbf{0 . 8 8 5}$ & \\
\hline 9. & TKDK $\left(\mathrm{X}_{8}\right)$ & $0.003^{* * *}$ & $\mathbf{0 . 1 9 6}$ & $\mathbf{4 . 5 0 4}$ \\
\hline 10. & TKLK $\left(\mathbf{X}_{\mathbf{9}}\right)$ & $\mathbf{0 . 6 1 8}$ & 0.005 & 0.679 \\
\hline Sigma-squared & $0.061^{* * *}$ & $\mathbf{0 . 0 2 9}$ & $\mathbf{2 0 . 9 4 9}$ \\
\hline Gamma & $0.999^{-}$ & & \\
\hline Log-likehood OLS & 4.708 & & \\
\hline Log-likehood MLE & 12.030 & & \\
\hline
\end{tabular}

Table 5 shows that the red chili production, seedlings price, Phonska fertilizer price, fungicides price, and the wage of non-family labor (TKLK) had a significant effect on the cost-efficiency of the red chili farming in Wukirsari Village. The production of red chili had a significant negative coefficient at a $99 \%$ confidence level. It can be assumed that the more production of red chili the higher the profits obtained by farmers. Thus, production costs can be reduced.

Furthermore, variables of seedlings, Phonska fertilizer, fungicide, and TKLK were found to have positive parameters. The addition of seedlings to the red chili farming in Wukirsari Village would significantly increase production costs at a 95\% confidence level. As for each addition of Phonska fertilizer, fungicide, and TKLK fertilizer variables, it was expected to increase production costs at a $99 \%$ confidence level. It is because the addition of prices to each variable would greatly affect the increase in production costs.

The choice of input prices used was inseparable from the influence of the internal factors of farmers. Hence, these internal factors of farmers were a function of cost inefficiency. Just like technical inefficiencies, the results of the estimation of the cost inefficiency function were also obtained from the MLE method available in the analysis of the Cobb-Douglas Stochastic Frontier production function as a delta. The results of the estimation of cost inefficiencies are as follows. 
Table 6. Estimation of Cost Efficiency Effects on Red Chili Farmers in Wukirsari Village

\begin{tabular}{|c|l|r|r|}
\hline Parameters & \multicolumn{1}{|c|}{ Variable } & Coefficient & t-count \\
\hline $\boldsymbol{\delta}_{\mathbf{0}}$ & Constant & $\mathbf{0 . 6 7 0}$ & *.039 \\
\hline$\delta_{1}$ & Age $\left(\mathrm{Z}_{1}\right)$ & 0.0006 & 0.085 \\
\hline$\delta_{2}$ & Education level $\left(\mathrm{Z}_{2}\right)$ & 0.018 & 1.244 \\
\hline$\delta_{3}$ & Farming experience $\left(\mathrm{Z}_{3}\right)$ & -0.002 & -0.457 \\
\hline $\boldsymbol{\delta}_{\mathbf{4}}$ & Land tenure status $\left(\mathbf{Z}_{\mathbf{4}}\right)$ & $\mathbf{- 0 . 4 2 2}$ & \\
\hline
\end{tabular}

$\begin{array}{ll}\text { Notes: } & \\ * * * & : \text { significantly affect on the level of } \alpha 1 \% \\ * * & : \text { significantly effect on the level of } \alpha 5 \%\end{array}$

Table 6 shows that land tenure status is the only variable having significant value. Moreover, age and education level show a positive coefficient, meaning that the addition of each unit value of each variable will cause farmers to become more inefficient in terms of cost. Moreover, both farming experience and land tenure status were found to be negative, which means that the addition of each unit of value of the two variables will lower the inefficiency of costs.

Regarding age and education level variables, the results show positive coefficient values. It could be due to the older the farmers, the less selective they are about prices. The education level variable indicates that the higher the education level, the more inefficient the cost would be. It could be estimated because farmers with higher education preferred high prices inputs for having better quality.

In terms of duration of farming experience and land tenure status, both were found to have negative values. The duration of farming shows a non-significant value. It was because of the long experience of farmers providing the network and experience related to the purchase of inputs providing lower prices. Therefore, production costs can be reduced.

The land tenure status was significant at the $99 \%$ confidence level. It was due to farmers having their own land status who were native and hereditary, making them familiar with the situation and conditions related to the place and price of the inputs used in the red chili farming.

\subsection{Allocative and Economic Efficiency}

Furthermore, price or allocative efficiency and economic efficiency were measured using a dual cost frontier derived from the stochastic frontier function. The results of the distribution of allocative and economic efficiency index are presented in Table 7.

Table 7. Distribution of Allocative and Economic Efficiency Index of Red Chili Farmers in Wukirsari Village

\begin{tabular}{|l|c|c|c|c|}
\hline \multirow{2}{*}{$\begin{array}{c}\text { Efficiency Index } \\
\text { Distribution }\end{array}$} & \multicolumn{2}{|c|}{ Allocative Efficiency } & \multicolumn{2}{c|}{ Economic Efficiency } \\
\cline { 2 - 5 } & Total & Percentage & Total & Percentage \\
\hline$\leq 0.500$ & 2 & 2.50 & 12 & 15.00 \\
\hline $0.501-0.600$ & 5 & 6.25 & 13 & 16.25 \\
\hline $0.601-0.700$ & 12 & 15.00 & 22 & 27.50 \\
\hline $0.701-0.800$ & 21 & 26.25 & 17 & 21.25 \\
\hline $0.801-0.900$ & 20 & 25.00 & 10 & 12.50 \\
\hline $0.901-1.000$ & 10 & 12.50 & 6 & 7.50 \\
\hline$>1.000$ & 10 & 12.50 & - & - \\
\hline Mean & & 0.804 & & 0.665 \\
\hline Maximum & & 1.116 & & 0.999 \\
\hline Minimum & & 0.428 & & 0.347 \\
\hline
\end{tabular}


The level of price or allocative efficiency achieved by red chili farmers in Wukirsari Village ranges between 0.428 to 1.116 with an average allocative efficiency of 0.804 , meaning that farmers still had the opportunity to increase their efficiency level by $28.00 \%$ $(1-(0.428 / 1.116))$.

The combined effect of technical and allocative efficiency shows the level of economic efficiency, in which the distribution of the index ranges from 0.665 to 0.999 , with an average of 0.347 . It indicates that if the average of farmers in the sample could achieve maximum economic efficiency, the red chili farmers in Wukirsari Village could save costs by $33.5 \%$ (1-(0.665/0.999)), while for inefficient farmers, they could save 65.2\% (1-(0.347/0.999)).

Based on the analysis of the overall values of efficiency, it was found that the average of each efficiency index was 0.826 for technical efficiency, 0.804 for allocative efficiency, and 0.665 for economic efficiency. These results indicate that the red chili farmers in Wukirsari Village had reached technically efficient. Meanwhile, economically, they can be said to be inefficient. However, farmers still had the opportunity to improve efficiency, both technical, allocative, and economy. The increase in the level of economic efficiency was focused on allocative efficiency, of which the value was less than the efficiency index $(\leq 0.700)$, which ultimately impacted the value of economic efficiency, which was a combination of technical and allocative efficiency. It referred to the average technical efficiency index of red chili farmers in Wukirsari Village that had reached an efficient status (efficiency index $>0.700$ ). Hence, the possible way to improve economic efficiency could be carried out by saving costs.

Therefore, saving costs was one of the possible ways to improve economic efficiency. It could be carried out through improving farm management quality related to the calculation of costs and the allocation of production factors. The same results are shown in the research of [15] stating that the production factors used by farmers were economically inefficient. Thus, farmers required to increase the use of fewer production factors or reduce excessive production factors to achieve economic efficiency in chili farming in Sumowono District.

\section{Conclusion and Suggestion}

\subsection{Conclusion}

The factor of land area and manure significantly affected the production of red chilies in the eruption area of Merapi. The seed factor, NPK Mutiara fertilizer and fungicide were positively related to the production of red chilies but had no significant effect, while the Phonska fertilizer, insecticide, and labor factors had a negative and insignificant relationship. The four internal factors of farmers had an insignificant influence on technical inefficiencies with positive parameters on the age variable, while other variables, such as education level, farming experience, and land tenure status, showed negative values. The efficiency of red chili farming in the eruption area of Merapi has reached technical efficiency with an average index of 0.826 and a price efficiency of 0.804 , but economically, farmers are not efficient because the efficiency level is only 0.665 .

\subsection{Suggestion}

Increase the technical efficiency of red chili farming by adding more inputs, especially for inputs that are responsive to increased production, namely land area and manure. In addition to increasing input, farmers also reduce inputs that tend to be excessive, such as Phonska fertilizers, insecticides, and labor. Increasing economic efficiency can be focused on through cost savings, namely by obtaining low input prices so as to achieve minimum costs. 


\section{References}

1. H. Imtiyaz, B. H. Prasetio, and N. Hidayat, J. Pengemb. Teknol. Inf. Dan Ilmu Komput. 1, 733 (2017).

2. J. Juhariah, Z.-E. Chen, L.-F. Yu, and N. Dong, 1, 1 (2020).

3. BPS, Kabupaten Sleman Dalam Angka SlemanRegency InFigures 2020 (Kabupaten SLeman Yogyakarta, 2020).

4. J. Asravor, E. E. Onumah, and Y. B. Osei-asare, J. Agric. Ext. Rural Dev. 8, 99 (2016).

5. Susanti, Efisiensi Teknis Usahatani Cabai Merah Keriting Di Kabupaten Bogor: Pendekatan Stochastic Production Frontier Susanti, 2014.

6. D. S. Siahaan, K. Tarigan, and T. Sebayang, J. Agric. Agribus. Socioecon. 1 (2015).

7. A. Anjarwati, E. Istiyanti, and U. Hasanah, Surya Agritama 2 (1), 11 (2013).

8. Saptana, A. Daryanto, H. K. Daryanto, and Kuntjoro, J. Manaj. Agribisnis 7, 115 (2010).

9. W. Krasachat, Annu. Conf. Agric. Econ. Soc. R. Dublin Soc. Dublin, Irel. (2017).

10. A. G. Kartasaputra, Pengantar Ekonomi Produksi Pertanian (Bina Aksara, Jakarta, 1988).

11. (n.d.).

12. A. Y. Fadwiwati, S. Hartoyo, S. U. Kuncoro, and I. W. Rusastra, J. Agro Ekon. 32, 1 (2016).

13. K. Ogundari and S. Ojo, Bulg. J. Agric. Sci. 13, 185 (2007).

14. A. Salihu, H. Singh, S. Safiyanu, and M. Hassan, Niger. Ann. Pure Appl. Sci. 3, 108 (2020).

15. E. Penggunaan, F. Produksi, U. Cabai, K. Sumowono, and K. Semarang, Econ. Dev. Anal. J. 2, 446 (2013).

16. S. H. Chonani, F. E. Prasmatiwi, and H. Santoso, J. Ilmu Ilmu Agribisnis 2, 99 (2014).

17. K. Sukiyono, J. Agro Ekon. 23, 176 (2016).

18. Kumbhakar SC \& Lovell CAK, Stochastic Frontier Analysis (n.d.).

19. M. Fauzan, Agrar. J. Agribus. Rural Dev. Res. 2, 107 (2016).

20. L. Rahayu, E. Febriana, and E. Istiyanti, IOP Conf. Ser. Earth Environ. Sci. 423, (2020).

21. S. Suharyanto, J. H. Mulyo, D. H. Darwanto, and S. Widodo, J. Penelit. Pertan. Tanam. Pangan 34, 131 (2015). 